\title{
Concerning Ernő Foerk's Documentation of Historic Monuments And Applied Arts aCtivities
}

\begin{abstract}
András Hadik
Before discussing the two areas of activity of the versatile architect Ernö Foerk, it is worthwhile to illuminate his family background and his early studies.

Ernő Tivadar Foerk [1] (Ernst Theodor Förk) was born on February 3, 1868 in the centre of the Banat region, in the rapidly developing Timisoara (today Timişoara-Romania).

Foerk's father, Karl Gustav Förk, was born in Altenburg, Saxony in 1815 [2]. He received a thorough education, but after his father's death he was forced to interrupt his studies, and undertook employment at the court printing house in his hometown. As an assistant - in Sweden and Norway, and then Germany, he "graduated" from his journey as an apprentice. In 1850 he arrived in Vienna. In 1852 he was invited to become a business manager at Márk Hazay's printing house in Timişoara. He soon moved to the State Printing House, and in 1857, together with the Steger printing house, purchased the Beichel family press. In 1858 he received Austrian citizenship and then civil rights in Timişoara. In 1868 they founded the Neue Temesvarer Zeitung. From 1871 he became the sole owner of the printing press. Förk edited the German calendar, was the responsible publisher of Temesvarer Wochenblatt and Der Sammler (The Collector), in which many of his stories and poems appeared. Among others, Südungarische Ackerbau-Zeitung, the Südungarische Lloyd, the Südungarische Bote, and the Timisoara Newsletter were produced at Förk's Press. He was president of the Printers' Aid Association of the town, which was the first such organization in Hungary and was also a member of the city council for several years. Ernö Foerk (according to his autobiography [3] written in a third person, "... because of the worsening economic conditions, his unconscious companion and his left-handed business manager, he had to give up his vineyard, his house, and even his printing house, and worked as an asistant in his own printing house." [4] Károly Gusztáv Förk died on October 5, 1884.

In the abovementioned resume, the architect writes that his drawing ability is a parental heritage, - his father engraved the letters and clichés himself, and his mother copied the fancy drawings of the time. His mother Mary Piffl came from Landskron in Northeastern Bohemia (Lanškroun, Czech Republic) and arrived in Timisoara with her parents around 1860. Her father, Adolf Piffl, was a book salesman. One relative pursued a career in the church: Friedrich Piffl (1864-1932) finished his career as the Archbishop of Vienna (1913).

Foerk's first drawing-related memory was that he drew on the floor sliding crawling on his knees. In his father's printing press he learnt to make lithography, posters, became familiar with bookbinding, and learned mirror writing while making business cards.

After completing his elementary school, Foerk studied at the private school of Franz Weiszner in 1878, then at the Timisoara Public Industrial School [5], where he already studied technical drawing and art history, and drew here for the first time after a plaster pattern. The director of the industrial school, Árpád Varjassy, was able to assess his talent because Foerk was awarded the city scholarship of 250 Florins to continue his studies in the capital.
\end{abstract}


His father could not finance it at that time, because he was bankrupt. Foerk arrived in Budapest in September 1884 and presented his drawings to the director of the middle school, Károly Hegedüs [6]. When the Director recognised his talent, he advised him to apply to the School of Applied Arts and ask for permission from his hometown. Permission arrived in two month's and he enrolled in the school's sculpture section. Meanwhile, his father dies and Foerk does not have enough money to go home to the funeral.

Lajos Mátrai [7], Foerk's sculpture teacher, had studied in Vienna, Paris and Munich and taught at the School of Applied Arts from 1880 onwards. He was influenced greatly by Albert Schickedanz, architect, painter and applied artist [8], designer of the Art Gallery, the Museum of Fine Arts and later planner of the Millennium Monument and succeeded in drawing his student's interest towards architecture. Some of his drawings made during his studies at the School of Applied Arts have been preserved in the Foerk legacy at the Hungarian Museum of Architecture: a plaster study of a goat from 1886, a male nude from 1887-88, a female nude from 1886, and a watercolor of a Renaissance fountain from 1888. After graduating from the School of Applied Arts, he spent one year in the office of architect József Pucher [9], where he gained insight into the practical work of the architect's office. He prepared the design of a gothic chapel in 1899 (main facade, facade, longitudinal section, cross-section) [10].

Probably Schikedanz encouraged and helped Foerk apply for the "King's Scholarship" to continue his studies. He received his scholarship and continued his studies at the Academy of Fine Arts in Vienna from the autumn of 1889.

\section{ATTENDANCE AT THE FRIEDRICH SCHMIDT MASTER SCHOOL IN VIENNA 1889-1892}

\section{Foerk's meeting with Monument Protection}

For Foerk, three years at the Vienna Academy of Fine Arts meant a decisive life cycle and experience. After the rapidly developing Timisoara and Budapest, the imperial city and the richness of its cultural life could have had a great impact on the young student. He was equally impressed by Professor Schmidt's individuality, art, and artistic approach, although at the midterm of his studies, the master died (January 23, 1891)

Friedrich Schmidt was born on October 23, 1825, in Frickenhofen (Würtemberg) [11] near Stuttgart. After completing the School of Sciences (1838), he studied at the Royal Industrial School in Stuttgart between 1840 and 1843, where Johann Matthäus Mauch (1792-1856), a former Berliner associate of Karl Friedrich Schinkel, taught the history of architecture. In 1843, Master Zwirner invited him assist in the construction of the Cologne Cathedral, where he worked as a stonemason. In 1848 he graduated from a stone carving and masonry master examination, and in 1855 in Berlin a masters degree. He is granted noble rank by Friedrich Wilhelm IV the Prussian King, and in 1856 he is appointed as the Inspector of the Cologne Cathedral. Later on, he is so proud of his Cologne work that, when he received a Baronic title in 1886, he included in his coat of arms his stone carving symbol used in Cologne. He worked for Vienna since 1854 (Austrian Veteran Memorial in Bensberg, near Cologne, the third prize-winning design for the Vienna Votive Church), and was invited as Professor at the then Academy of Fine Arts of the Habsburg Empire in Milan. Although he was well received there (he knew some Italian), this position was soon taken away by history. During the AustroPiedmont-France war, Milan was captured by the French-Piedmont troops, and he left Vienna after the Austrian defeat at Solferino. He was appointed Professor at the Academy of Fine Arts in Vienna on November 1, 1859, and later he was rector three times in the 1870 s. In 1864 he 
received Austrian citizenship, from 1865 he was the chief Councillor of Construction, from 1866 to 1870 he was a member of the Vienna City Council, in 1883 he became an honorary citizen of Vienna and from 1888 he was a member of the Upper House.

Schmidt was an architectural designer from 1847 onwards. Until 1858, this activity was centred on the Rhine, mainly churches. The first building in Vienna was the Neo-Gothic Academic High School on Beethovenplatz (1862-66). In 1863, Stephansdom's "Dombaumeister" worked on numerous variations for the restoration of this monumental building based on purist principles. One of his main works is the Neo-Gothic City Hall in Vienna, commissioned as the first prize winner of an international competition in 1869 . The construction takes place between 1873 and 1883, but the interior design and equipment are only completed in 1888. Designed in 1873, the Neo-Renaissance Arcade Houses on both sides of the Town Hall are being built by 1882 . From 1882 to 1886 , the one-time Imperial Foundation House was constructed on the Ringstrasse, which also houses a chapel where it was customary to pray for 386 victims of the Ringtheater burnt down in 1882. From 1886 he lives in a city apartment next to the villa in the Dornbach district. From 1874 to his death he plans and rebuilds the Abbey of Closterneuburg. Schmidt also received foreign commissions, eg he rebuilt the Main Post Office in Basel (18771880), and planned and built Baron Wrangel's castle in Kiev from 1879 to 1887. In Zagreb, Croatia, together with his German student who had moved to Zagreb, Hermann Bollé, Schmidt planned the neo-Renaissance building of the National Museum (1876-1884), and renovates the cathedral (1874-1885) and the Saint Mark's Church (1875-1882) Among the unimplemented plans in historic Hungary, one should mention the Holy Trinity column (1859) designed for Pest-Buda, a Protestant church of a non-deterministic character (around 1880), and the tomb of Albert Pákh at the Kerepesi cemetery (1868). In 1867 he designed the restoration of the Vajdahunyad Castle (Hunedoara-Romania) (1867-68), the family graveyard of the Apponyi family in Eberhard (Malinovo, today Slovakia) (1871). From 1872 to 1879 he restored the medieval church of Lébény, and in 1872 a residential building at No. 9 Vörösmarty Street in Pest. The most well-known building in Hungary is the Purist reconstruction of the Pécs dome (1882-1891). Through his architectural and monumental restoration activities, he became an unquestionable professional philanthropist throughout Central Europe, yet he also gained great influence through his teaching. His love for subject matter and his fascinating personality fascinated his disciples, many for life. Schmidt taught medieval styles, not in lengthy and tiring lectures, but in practical design. (This method was taken over by Imre Steindl at the Budapest University of Technology). The personal relationship and co-operation advocated the method and atmosphere of the 20th century master schools. Summer (occasionally mid-term) study tours, and common programs were an integral part of education. In 1862, architect students established their self-education association, which in 1864 became named Wiener Bauhütte (Vienna Building Alcove), remembering the medieval building organisations, and they elected Professor Schmidt as honorary president [12]. Since then, this organization has published holiday recordings, ie building surveys.

Schmidt's disciples were mainly from the German-speaking regions, or they came from the Empire (the Austro-Hungarian Monarchy). Ferenc Schulcz, a favourite student who died at a young age, Imre Steindl, and later gave a job to Foerk, Schulek Frigyes, Elder Ferenc Schömer, with whom Foerk won first prize at the Lipótváros Synagogue, Sándor Aigner, Antal Hofhauser, Sándor Mezey and Kálmán Stornó, or Gusztáv Petschacher, an Austrian, settled in Budapest all came from Hungary.

Friedrich Schmidt exerted a great influence on Foerk, which, on the one hand, manifested itself in his architecture, basically on the basis of Historicism, although sometimes he strayed in the direction of the Secession. At the completion of the Votive Church in Szeged, Foerk was proud to be also called the "Dombaumeister". For competitions he often chose 
Schmidt's favorite Latin password: Saxa locuuntur [13] - The stones speak. The practice of holiday monumental surveys was later used during the work of the Hungarian Royal Public Higher Architectural Industrial School, ie he continued the Viennese tradition here, and he also knew that publishing the materials motivated his students.

A design of a Renaissance pavilion [14] in Vienna from 1890 can be found in the Foerk Legacy of the Hungarian Museum of Architecture as well as the plan of a Gothic church [15] also from 1890, the design of a neo-Romanesque tomb [16], a plan in Romanesque style with a campanile [17] and a church plan in Gothic style [18] from 1891. The Budapest Historical Museum (Kiscell Museum) features Foerk's designs from 1892: a monumental neo-Renaissance spa [19] complex with a regular rectangular plot surrounded by a single-storey building with an open-air swimming pool and a large dome-covered spa, or a neo-Romanesque Pantheon dome [20]. Foerk received three different academic awards for his beautifully drawn and coloured drawings.

From the records of the Vienna Academy it turns out that Foerk rented rooms in the IX. district Severingasse 3 as a first year student, then between 1890 and 92 in the VIII. District Kochgasse 25 (1st floor Apt. 8). The Hungarian Museum of Architecture contains a lazy watercolor (1889) entitled "The Main Cave of the Hungarian Band of the K.K." Foerk, F.Lővy, Frank and Jankov (ics?), who have to be identified by the research, are included in this picture. From his sketches of monuments, the drawing of the parish church in Iglau ( Jihlava, Moravia), the two details of the Upper Austrian Imbach church ( tower, side-aisle window), restored by Schmidt and the details of the St. Altmann memorial of the founder of the the Benedictine abbey church and monastery in Göttweig, all from 1890.

The Art Academy of Vienna (Kupferstichkabinett) also holds 11 survey drawings by Foerk. Two of these depict Göttweig tombs, and three of them were made in Krems on the Danube: one of a group of urban houses, another the painted gothic ribs (Ill. 1) [21] inside the former Dominican church (first picture) and one of the pillar capitals of the "fruit store" (Ill.2) [22]. The remainder are of the medieval church of Trebitsch (Třebič) in Moravia and its details. Also the details of a small town Moravian church from 1891, - the portal and its carvings - are presented in four nicely drawn pages of the Hungarian Museum of Architecture. There are also three sketches of Craiova (1891 - Wallachia), two of which represent the tower and iron gate of St John's Church, and one of a beautiful, columned stove. There is also a fine drawing of the medieval dome of Gelnhausen [23] near Frankfurt am Main from this year. Foerk's survey drawings show good observation and compositional skills as well as excellent drawing skills.

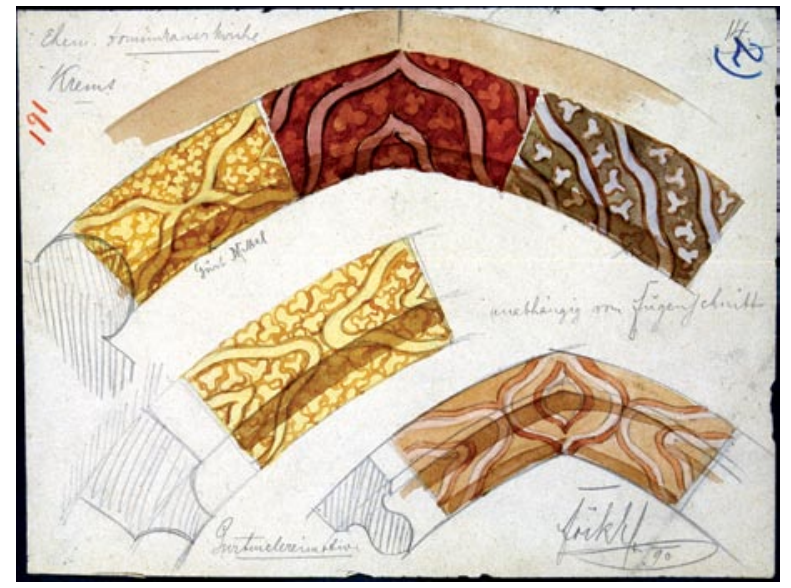

1. Krems, painted ribs of a former Dominican church 


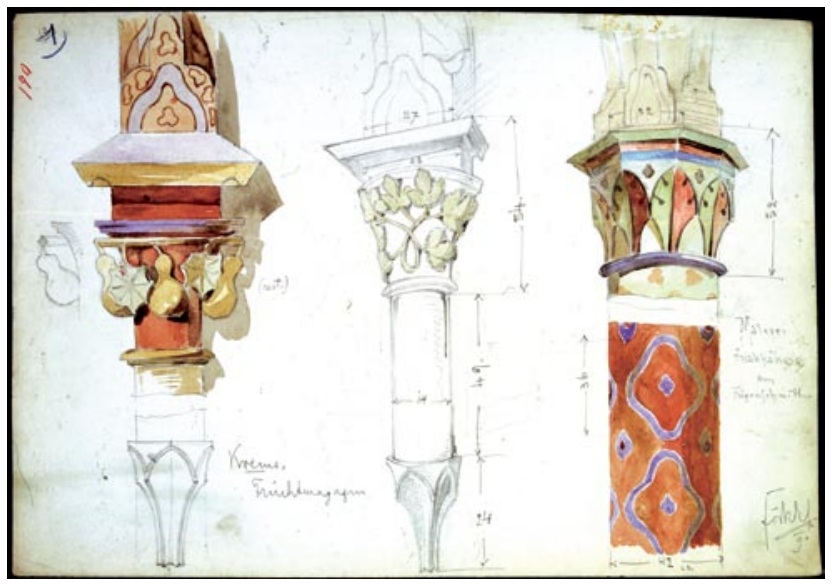

2. Krems, the Column capitals of the "Fruit Store", 1890

\section{Foerk's Applied Arts activities}

As we have already mentioned in the introduction, Foerk learned a lot from his father's press in the field of applied graphics. He later developed his skills at the School of Applied Arts. Probably in the "90s (after 1892), two versions of the design for a "Receipt", include one with a Rococo border [24] for the text. More interesting is the version in which the frame is created by asymmetric visual architecture [25] (or furniture). (Ill. 3) The acronym on the left side solves the mystery for the customer - the two versions were created for the Hungarian Royal Applied Arts Society, characterised by historicist views. In 1898 Foerk also participated in a stamp competition. At the turn of the century, three poster designs [26] made for the Museum of Applied Arts "Modern Art" Exhibition invite visitors to the exhibit. (Ill.4)

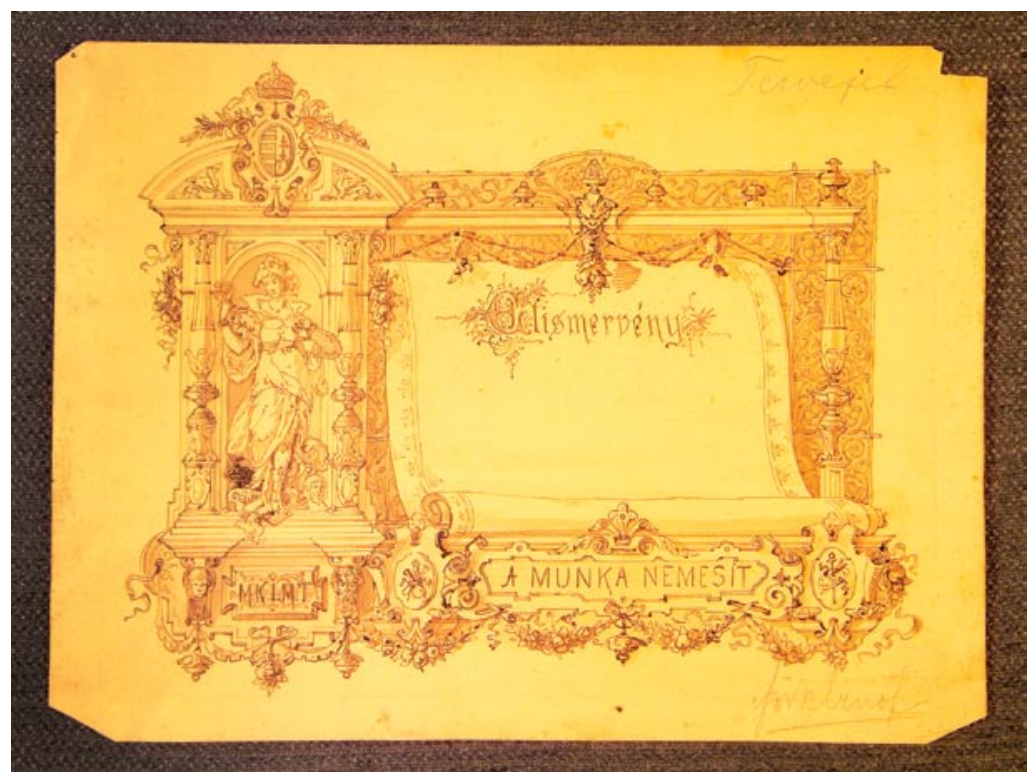

3. The design of the "Receipt" for the Society of Applied Arts, 1890s 
These show the strong influence of Art Nouveau and the knowledge of new artistic processes. While the art of the Secession is rarely seen in Foerk's architecture, he is more eclectic in his craftwork. Foerk also makes cover designs, eg. In 1901, Károly Lyka edited Müvészet (Art), and is especially interesting for a series of books (Great Hungarian Writers). On one of them, a floral motif [27] with a stylized folk floral pattern appears, similar to that used in a parliamentary furniture design. (Ill. 5) The János Arany volume's cover is a secessionist solution of a dynamic, asymmetric tree motif. (Ill. 6) [28]. From 1892 to 1902, Foerk worked in the Steindl office for the interior design of the Houses of Parliament. This created the opportunity to use the lessons learned so far in many areas of the Applied Arts. Foerk participated in the design of the decorative painting of the building, which he puts to great use in his later work (eg. in the case of the Votive Church of Szeged). He designed several pieces of furniture for the bulding, eg. The Prime Minister's desk, decorated with Zsolnay ceramics, will be executed by Endre Thék's furniture factory according to his plans. (The furniture found in the warehouse was restored in the early 2000s). The Parliament's furniture is more traditional, but later Foerk also produces Art Nouveau furniture designs. An interesting wardrobe design is traditional in mass, but in its painting we can already feel the liberation effect of Art Nouveau. (Ill.7). He also makes plans for metal furniture. The Art Nouveau-style letterbox design, designs for clocks (standing and wall clocks) and jewellery testify to an affinity with metalwork. Special Art Nouveau Hairpins from 1901 (Ill. 8), Chandeliers (eg for Parliament) [29] and Churches or the Steindl Guild attest to good taste. Foerk designed a badge, stamp and bell for the Steindl Guild. During his career he also designed curtains [30] and a flag [31].

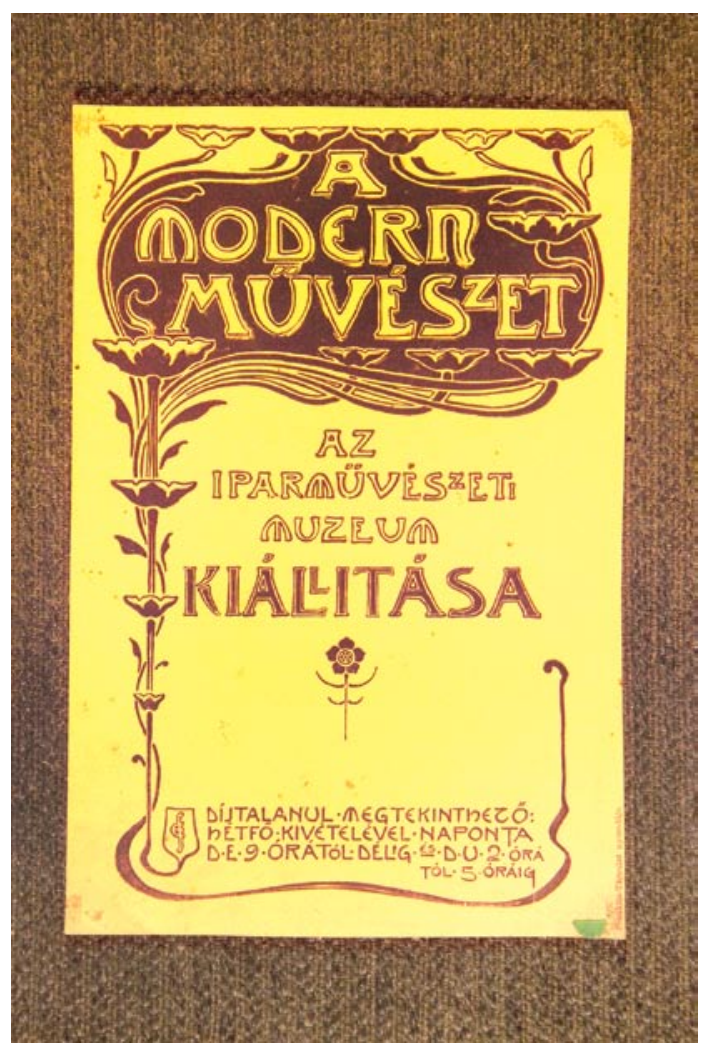

4. Design of an exhibition poster of the Museum of Applied Arts in 1898 
This article aims to show the terrain of Ernő Foerk, a versatile architect. During his academic studies in Vienna, the architect became familiar with the principles of modern monument protection of that time, and with the architecture of the different ages, which he later used as a regular member of the National Committee for Monuments and was transplanted into Hungarian practice during the holiday surveys at the Higher School. At the same time, his knowledge of his father's office in Timisoara, at the School of Applied Arts and at the Vienna Academy were utilised in his work as a versatile applied artist. For him, architecture was formulated as „Gesamtkunst”, a total art. Foerk's importance can be further clarified by further research.

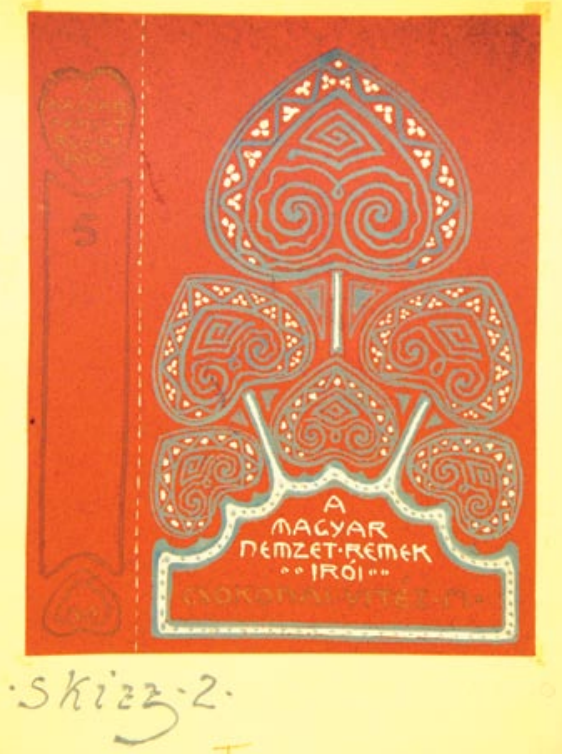

5. Book Series (Great Hungarian Writers) cover design early 1900s

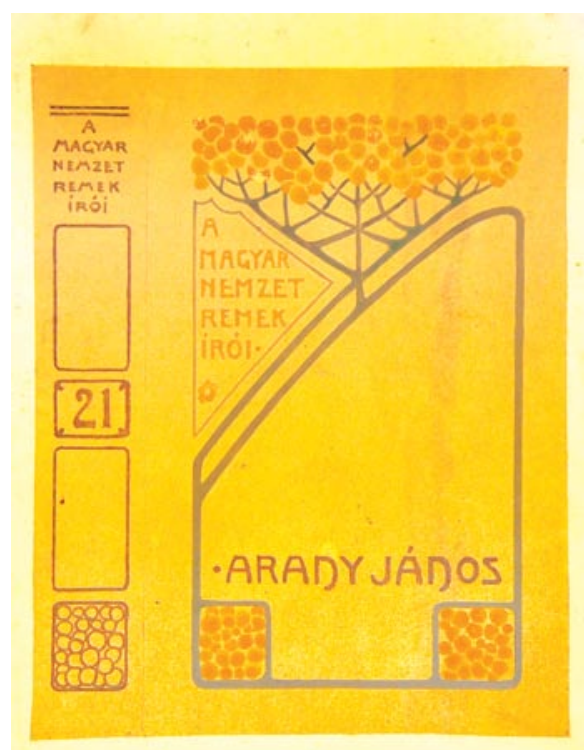

6. Book Series (Great Hungarian Writers), Early 1900s 


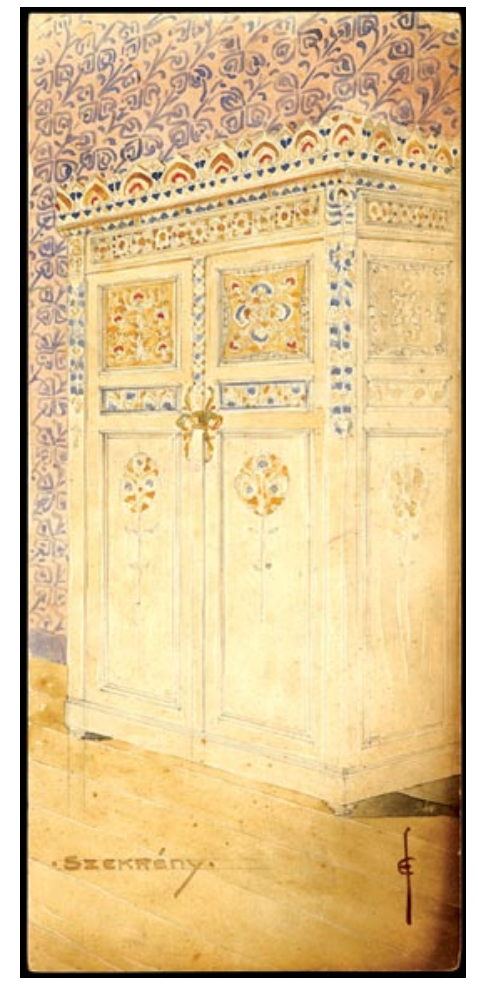

7. Cabinet design $1900 \mathrm{k}$.

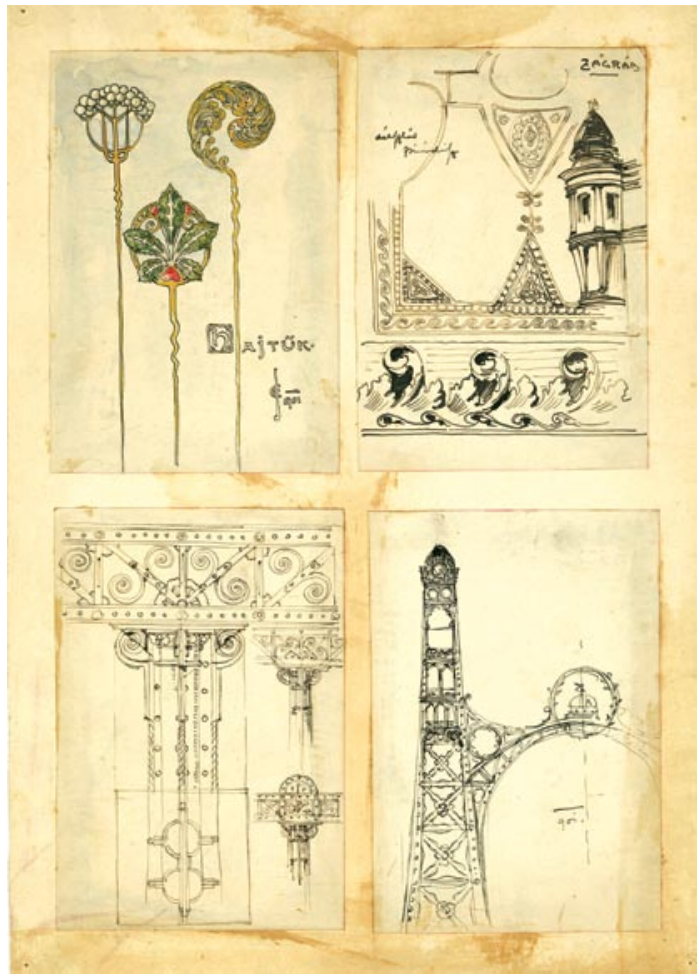

8. Sketches, including plans for hairpins 1901.

\section{REFERENCES}

[1] He writes his surname in 1904 in this form.

[2] István Berkeszi: The History of Book Printing and Newspaper Literature in Timisoara, Historical and Archeological Notice in Timisoara, 1899. I-II. booklet. I am grateful to Ilona Mikósik, the art historian of the Banat Museum (Muzeul Banatului) in Timisoara, who sent me the publication.

[3] The typed text is owned by the family

[4] Foerk's Diary (MÉM) entry, month 1913.

[5] His certificates are at the BTM Kiscelli Museum.

[6] Károly Hegedűs mechanical engineer (Szatmárnémeti 1849-Budapest 1925) graduated from the Technical University in Budapest. Between 1876 and 78 he studied industrial education in England, France, Germany and Switzerland on behalf of the government. He organized the middle school (since 1879) and the director of the Technological Industry Museum since 1884. Hungarian commercial and industrial principal director of the 1900 Paris World Expo, court advisor. Author of engineering and vocational education.

[7] Lajos György Mátrai (Pest 1850- Budapest 1906), his main works: the tomb of Miklós Izsó in the Kerepesi cemetery, Pál Vásárhelyi (Szeged), István Széchenyi (Sopron), Károly Kisfaludy (Győr), the tombs of Gáspár Károli (Gönc)

[8] Albert Schickedanz (Biala, today Bielsko-Biała-Poland 1846- Budapest 1915)

[9] József Pucher architect (1836-1904)

[10] Hungarian Museum of Architecture, Foerk legacy

[11] Dr. Peter Haiko, Dr. Renata Kassal Mikula (editors): Friedrich von Schmidt (1825-1891) Ein gotischer Rationalist, Historisches Museum der Stadt Wien (exhibition catalogue) 1991 
[12] JózsEF Sisa: Imre Steindl Holnap Press, Budapest 2005 p. 13

[13] Scmidt's tombstone, made by Victor Luntz, reads according to his last wish: „Saxa locuuntur. Here Friedrich Schmidt, a German stonemason, rests in God.” Cat Dr. Peter Haiko, Dr. Renata Kassal-Mikula. Friedrich Schmidt. Vienna, 1991 p.79

[14] Inv. no. 69.024.701

[15] Inv. no. 69.024.757

[16] Inv. no. 69.024.217

[17] Inv. no. 69.024.339

[18] Inv. no. 69024.625

[19] Inv. no. 69207.2

[20] Inv. no. 69.211.1

[20] Inv. no. 20/104/25 752

[22] Inv. no. 20/104/25753

[23] Inv. no. 69.024.692

[24] Inv. no. 69.228.4/2

[25] Inv. no. 1tsz.69.228. 4/1

[26] Inv. no. 69.228. 4/5-7 dated to 1898 according to Foerk's diary.

[27] Inv. no. 69.228.1/6 Published in the Steindl monograph by József Sisa.

[28] Inv. no. 69.228.1/3

[29] in the collection of chandeliers of Parliament there is an example which uses uses Hungarian floral motifs.

Dorottya Andrássy The History of Parliament's Construction Bp. 2018. p.

[30] Foerk's Diary January 16, 1898

[31] Flag of the National League of War Cripples 1932. 